\title{
Neuroendoscopic Foraminoplasty for Bilateral Idiopathic Occlusion of Foramina of Monro
}

\section{Bilateral Foramen Monro Oklüsyonunda Nöroendoskopik Foraminoplasti}

\author{
Guive SHARIFI, Ehsan ALAVI, Omidvar REZAEE, Amin JAHANBAKHSHI, Faezeh FARAMARZI \\ Shabid Beheshti University of Medical Sciences, Department of Neurosurgery, Tehran, Islamic Republic of Iran
}

Correspondence address: Guive SHARIFI / E-mail: sharifi@sbmu.ac.ir

\begin{abstract}
We report the safety and efficacy of bilateral foraminoplasty of Monro in a patient with partial occlusion of right Monro and complete occlusion of the left one. A 38-year-old man who underwent a ventriculoperitoneal shunt three years ago, and shunt revision surgery twice, presented with hydrocephalus, and was referred to us because of continuing complaints of headaches, nausea and vomiting. The primary surgical treatment of the patient was bilateral endoscopic Monro foraminoplasty. Then, the patient did not need a ventriculoperitoneal shunt, and hydrocephalus was resolved. Bilateral monroplasty in a single-session surgery can be the treatment of choice, instead of microsurgically open reconstruction of the foramen of Monro. The procedure can be less invasive, and it avoids ventriculoperitoneal shunting.
\end{abstract}

KEYWORDS: Foramen of monro, Foraminoplasty, Hydrocephalus, Neuroendoscopy

Öz

Bu yazıda, sağ foramen monroda parsiyel ve sol foramen monroda tam oklüzyonu olan hastada yapılan bilateral foraminoplastinin etkinliği ve güvenilirliği sunulmaktadır. Üçyıl önce ventriküloperitoneal şant takılan ve iki kez revizyon ameliyatı yapılan 38 yaşındaki erkek hasta, sürekli olan başağrısı, bulantı, kusma yakınması ile kabul edildi. Hastaya bilateral endoskopik foraminoplasti yapıldı. Bundan sonra hastanın şant bağımlıığı ortadan kalktı ve hidrosefalisi düzeldi. Tek seansta iki taraflı monroplasti açık yolla yapılan foramen monro rekonstrüksiyonuna alternatif bir yöntem olarak düşünülebilir. Monroplasti daha az invaziv ve şant bağımlıı̆̆ını ortadan kaldıran bir yöntemdir.

ANAHTAR SÖZCÜKLER: Foramen monro, Foraminoplasti, Hidrosefali, Nöroendoskopi

\section{INTRODUCTION}

Occlusion of the foramen of Monro may be the result of several pathological conditions including neoplastic lesions (e.g. sub-ependymal giant cell astrocytoma, hypothalamic glioma), inflammatory conditions (e.g. bacterial ventriculitis, and brain abscess), congenital problems (e.g. choroid plexus cyst, and atresia of foramen of Monro), vascular anomalies (e.g. AV malformation of the choroid plexus $(4,14)$, and basilar artery aneurysm or ectasia (7)), or iatrogenic complications. Idiopathic occlusion of foramen of Monro, a situation in which no clue can be detected to the etiology of foraminal obstruction, is an extremely rare phenomenon in adults with only five cases of bilateral and ten cases of unilateral obstruction reported in the literature $(6,10-13,15)$.

In the mentioned reported cases, the different treatment modalities that have been used for such patients are divided into open surgical procedures including open microsurgical reconstruction of foramen of monro septum pellucidostomy and shunt placement, and endoscopic techniques (6), which as minimally invasive surgery should become the center of attention in selection of the appropriate approach for unilateral or bilateral occlusion of foramen of Monro.

Here, we report a case of bilateral idiopathic obstruction of foramen of Monro with consecutive hydrocephalus that was treated successfully by a single-session single-burrhole bilateral neuroendoscopic foraminal plasty without shunt placement.

\section{CASE REPORT}

The patient was a 38-year-old man with a four-year history of hydrocephalus and a ventriculoperitoneal shunt, performed three years ago in another center, that had been revised two times because of shunt malfunction during the period. The patient referred to our center because of recurrence of high ICP symptoms and signs, including headache, nausea, vomiting, vertigo, gait and balance disturbances, and bilateral papillary edema. Radiological examinations showed abnormal ventricular images including bilateral enlargement of the lateral ventricles, cystic fourth ventricle and normal to high size of the third ventricle (below $5 \mathrm{~mm}$ ) (Figure 1). After ventriculo-cysternography, we revealed the partial occlusion of CSF passage from lateral ventricles to $3^{\text {rd }}$ and $4^{\text {th }}$ ventricles and good subarachnoid space maturity and function.

At first, we had removed the ventricular catheter of VP shunt and then entered the ventricular system via a right precoronal burrhole, through the classical Kocher point (1 inch in front of the coronal suture and 1 inch lateral to the medial sagittal line), using a rigid Gaab neuroendoscope (Storz, Germany). The point of convergence of the choroid plexus, the 
thalamostriate vein, and the septal vein was used as a marker of the location of the foramen of Monro. A thin membrane, which resembled normal ependyma, had occluded most of the surface of the right foramen of Monro. The size of the remaining opening was about $1.5 \mathrm{~mm}$ so that the tip of the fogarty catheter No.3 could pass through it with difficulty. The configuration of the foramen, and the position of veins partially embedded in parenchyma indicated a congenital anomaly. The foramen was reconstructed by blunt perforation and dilation of the membrane. After we reconstructed the right Monro, the septum pellucidum was fenestrated (septostomy) (Figures 2, 3A,B). With a good access to the left ventricle, inspection revealed complete occlusion of the left foramen of Monro with disfigured foramen. After perforation and dilation of the left foramen, we placed an extraventricular drainage system for ICP monitoring. We did not perform third ventriculostomy because despite good foraminoplasty, we had no good space to reach the floor and the reconstructed foramen was still smaller than the tip of the endoscope (i.e. $6.4 \mathrm{~mm}$ ). Pathological specimens showed normal ependymal tissue.
The postoperative course was uneventful. The patient showed notable improvement of the presenting symptoms. We monitored ICP three times every day for three days after surgery. While the ICP was $11 \mathrm{~cm} \mathrm{H}_{2} \mathrm{O}$, the EVD was removed. Serial tomographic scans showed decreasing of both lateral ventricle diameters and $M R$ imaging revealed decreased ventricular sizes (Figure 4A-D). The initial symptoms had completely resolved 3 months after surgery. Now, two years after endoscopic surgery, the patient is still symptom free and shunt independent and the ventricular size is quite normal (Evan's ratio $<35 \%$ ).

\section{DISCUSSION}

Obstruction of the Monro foramen and consecutive hydrocephalus may be the result of thalamic and intraventricular neoplasia, colloid cysts, tuberculous masses, ventriculitis, vascular malformations and non-specific inflammatory conditions $(1,4,6,7,14)$. Idiopathic occlusion of the foramen of Monro, a condition in which no background pathology could be found, is an extremely rare phenomenon, in which the foramen of Monro may be occluded by a membrane or may be atretic $(5,16)$.
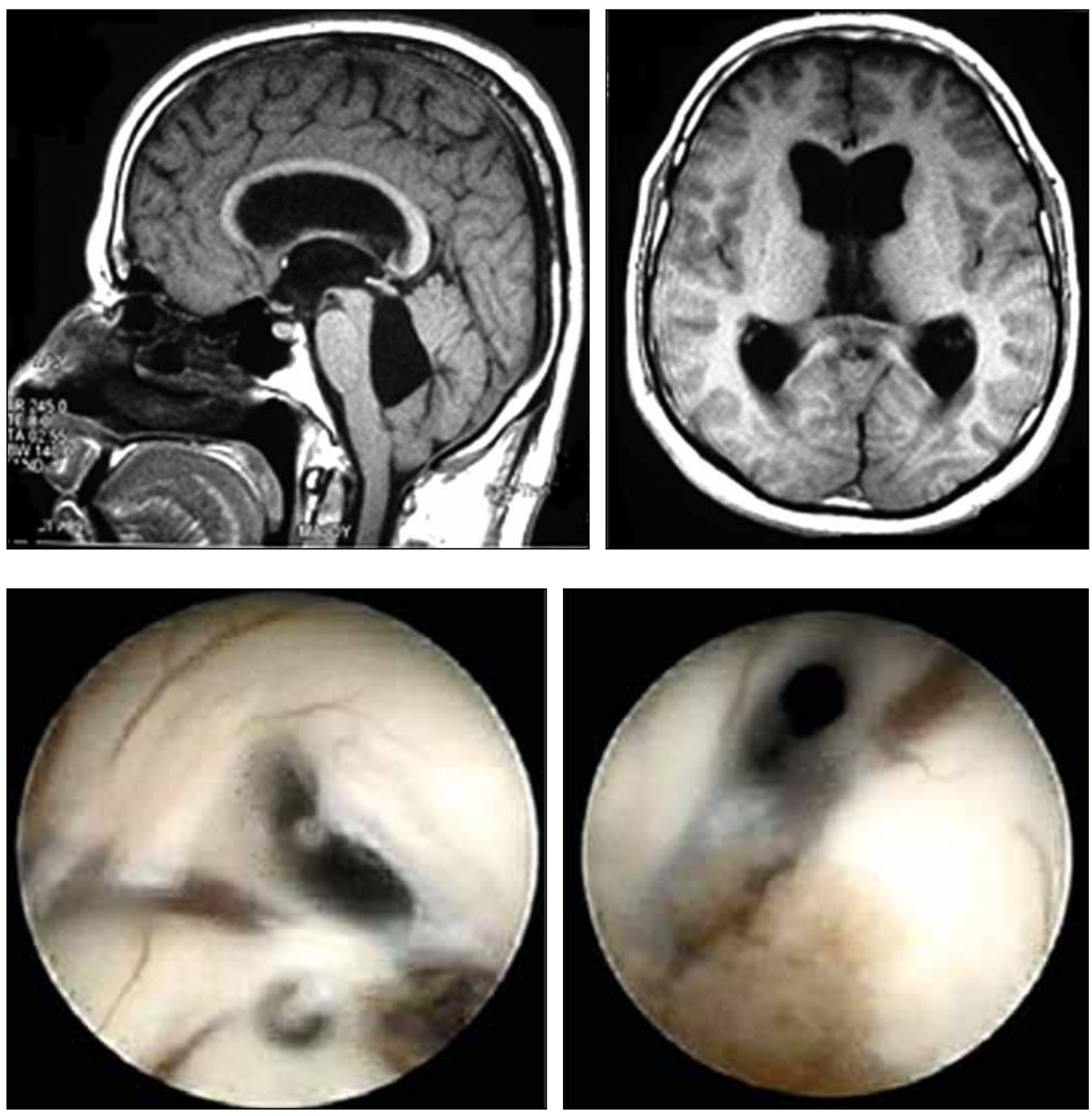

Figure 1: Preoperative axial and sagittal magnetic resonance images revealing dilation of the bilateral lateral ventricles and abnormal cystic forth ventricle.

Figure 2: left: deformed and completely occluded left foramen of Monro before foraminal plasty, right: partially occluded right foramen of Monro before foraminal plasty (note the distance between choroid plexus and monro. 
It is not clear why such patients of idiopathic hydrocephalus that probably have had this pathology congenitally, may present so late in adulthood. Some adaptational mechanisms, parenchymal absorption, could be suggested as a reason for such a late presentation by attenuation of the severity of hydrocephalus (9). Specifically, CSF absorption in hydrocephalus by a transparenchymal pathway into the cerebral vasculature was reported in a murine model (3). Alterations in CSF secretion and circulation or valve mechanism similar to what is described for stenosis of aqueduct of Sylvius, also, may have a role in the delay in evolution of the symptoms $(2,6)$. Such cases might not
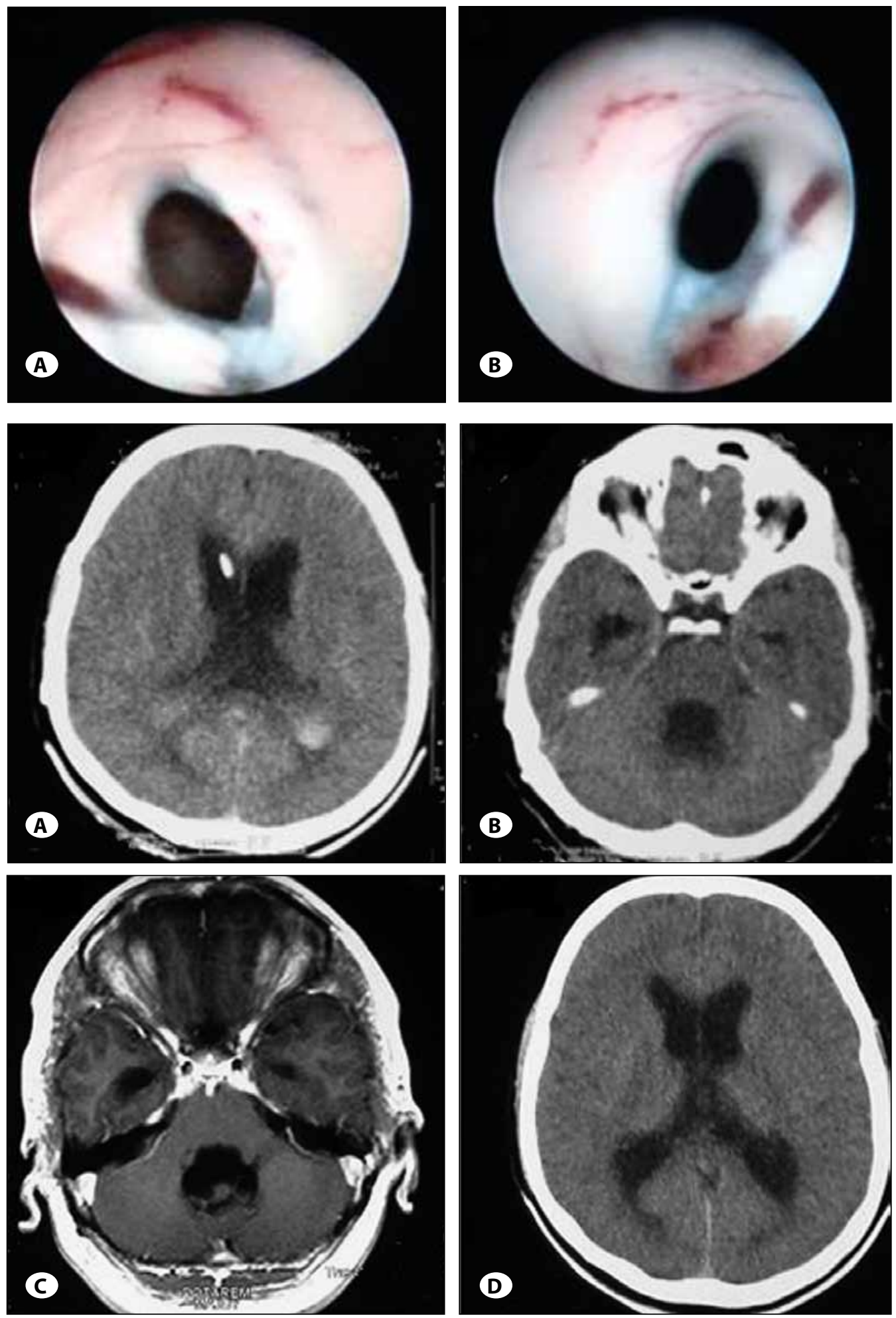
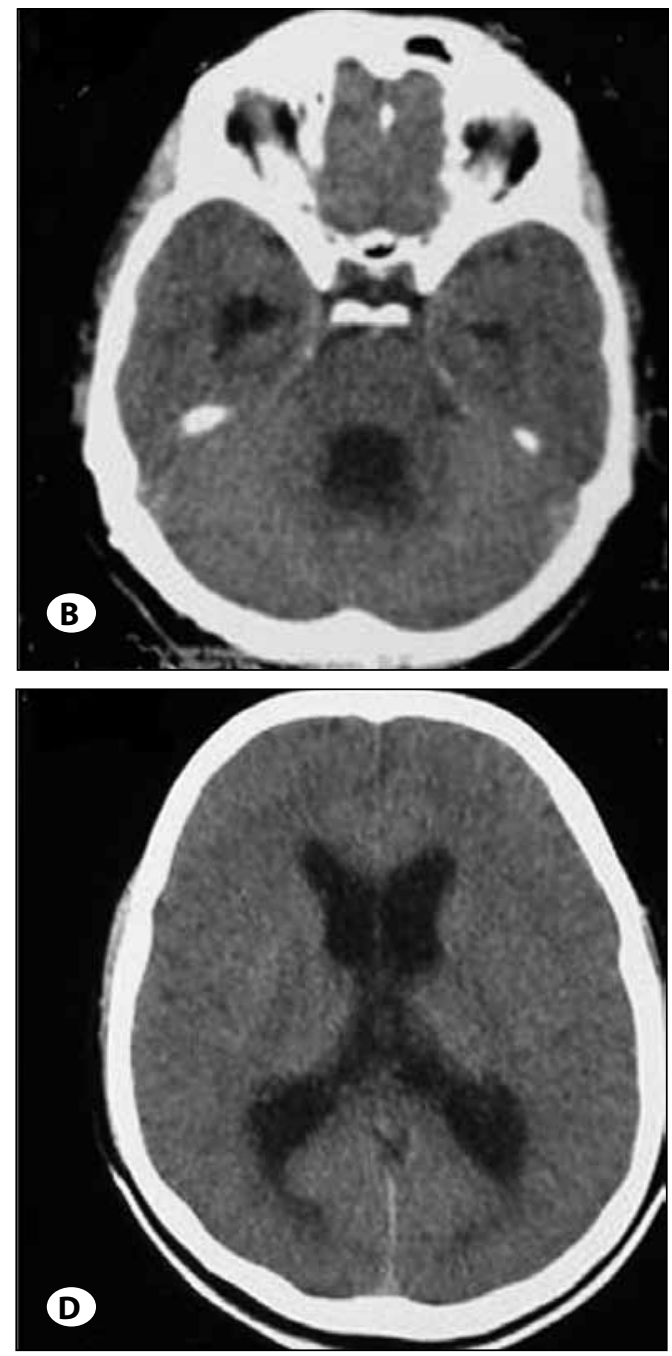

Figure 3: Postoperative Monro foramens (A: left, B: right). The thin membranes were perforated and the foramens were dilated.

Figure 4: A, B: Preoperative ventriculography from patient's ventriculoperitoneal shunt revealed patent $4^{\text {th }}$ ventricle and good subarachnoid space function. C) Pre-operative axial MRI shows cystic dilation of $4^{\text {th }}$ ventricle. D) post-operative tomographic scan after neuro-endoscopic foraminal plasty and externalization of the shunt and EVD. 
completely be asymptomatic when the past symptoms are asked insistently. But, mild symptoms do not make them seek clinical consultation.

Different treatment modalities that have been used for these patients are craniotomy and fenestration of the pellucidum for unilateral hydrocephalus (9) and bilateral midline windowing of the $3^{\text {rd }}$ into the lateral ventricle for bilateral hydrocephalus (12). Marions et al. introduced two cases of bilateral occlusion of the foramen of Monro; one of them was treated by open microsurgery and the other with a ventriculoperitoneal shunt. Freudenstein et al. introduced two cases of bilateral idiopathic occlusion of the foramen of Monro. For the first patient, on the right side, endoscopic reconstruction of the foramen was performed while a spontaneous perforation of the septum pellucidum existed before that. At least for this patient a VP shunt became necessary for ICP rising three days after surgery. In the other case, unilateral foraminoplasty plus septum pellucidostomy and third ventriculostomy were performed. The procedure introduced in this issue is unique for the novelty of technique: neuroendoscopic singleburr hole bilateral Monro foraminoplasty that has not been introduced elsewhere. Septum pellucidostomy, alone, might not guarantee the passage of CSF of both ventricles through the, already reconstructed, foramen of Monro. So, we decided to perform foraminoplasty for the contralateral foramen. Making a burr hole more medially, makes the access possible for both foramina simultaneously. In Freudenstein's patients, the other foramen of Monro was only inspected because of poor access.

Our adult patient presented with symptomatologic idiopathic occlusion of both foramina of Monro unrelated to neoplastic or inflammatory conditions. In adult hydrocephalic patients, where we presume the subarachnoid space would have maturity and good function, we can choose the cerebrospinal fluid system reconstruction as the only main and needed treatment. In pre-operative investigation, we have done the ventriculo-cysternography via the ventricular head of existing shunt because the abnormal shape and cystic dilation of the $4^{\text {th }}$ ventricle made us uncertain about a normal relation between the $4^{\text {th }}$ ventricle and subarachnoid spaces and also for the investigation of the maturity and function of the subarachnoid space.

We also had performed ventriculo-cysternography because of abnormal dilation of the fourth ventricle and the major presumed cause for such a condition is fourth ventricle outlet obstruction. The pre-operative ventriculography (Figure 4AD) revealed apparent patency of the aqueduct and partial patency of at least one of Monro foramen as one can see the contrast enhancement in sabarachnoid space. The cystic shape of fourth ventricle (Figure 1) and patency of aqueduct made us accept that there is somehow a disproportionately large communicating fourth ventricle (DLCFV). Weakness to CSF pressure of brain stem parenchyma around the fourth ventricle is the main cause of this phenomenon (8). We argue that the case was a rare combination of bilateral idiopathic Monro occlusion and cystic dilation of $4^{\text {th }}$ ventricle with patent aqueduct that recovered completely with endoscopic surgery and did not need third ventriculostomy.

\section{CONCLUSION}

Neuroendoscopic treatment provides both direct visualization of the nature of the obstruction and the opportunity of taking a biopsy specimen, as well as the possibility of treatment through fenestration or reconstruction. The procedure is less invasive than open microsurgical reconstruction and can simplify or even avoid ventriculoperitoneal shunting.

\section{REFERENCES}

1. Aldana PR, Kestle J RW, Brockmeyer DL, Walker ML: Results of endoscopic septal fenestration in the treatment of isolated ventricular hydrocephalus. Pediatr Neurosurg 38: 286-294, 2003

2. Balakrishnan V, Dinning TA: Non-neoplastic stenosis of the aqueduct presenting in adolescence and adult life. Surg Neurol 7:333-338, 1977

3. Bloch O, Auguste KI, Manley GT, Verkman AS: Accelerated progression of kaolin-induced hydrocephalus in aquaporin4-deficient mice. J Cereb Blood Flow Metab 26: 1527-1537, 2006

4. Britt RH, Silverberg GD, Enzmann DR, Hanbery JW: Third ventricule choroid plexus arteriovenous malformation simulating a colloid cyst. Case report. J Neurosurg 52: 246-250, 1980

5. Dorwling-Carter D, Scherpereel B, Baudrillart JC, Omez F, Lejeune JP, Rousseaux P, Motte J: Unilateral non-tumor hydrocephalus in children. Atresia of the foramen of Monro?. Neurochirurgie 33:129-134,1987

6. Freudenstein D, Duffner F, Krape $H$, Wagner A, Grote EH: Neuroendoscopic treatment of idiopathic occlusion of the foramen of Monro in adults: Two case reports. Neurol Med Chir 42:81-85, 2002

7. GreitzT, Ekbom K, Kugelberg E, Breig A: Occult hydrocephalus due to ectasia of the basilar artery. Acta Radiol Diagn (Stockh) 9: 310-316, 1969

8. Hagihara N, Sakata S: Disproportionately laarge communicating fourth ventricle with syringomyelia, Neurol Med Chir 47: 278-281, 2007

9. Levine DN: The pathogenesis of normal pressure hydrocephalus: A theoretical analysis. Bull Math Biol 61: 875-916, 1999

10. Mampalam TJ, Harsh GR, Tien RD, Dillon WP, Wilson CB: Unilateral hydrocephalus in adults. Surg Neurol 35: 14-19, 1991

11. Marions $\mathrm{O}$, Boethius J: Congenital constriction of the foramen of Monro. Neuroradiology 28:275-278, 1986

12. Maxwell JA, Stimac GK: Adult "congenital" bilateral occlusion of the foramina of Monro. Surg Neurol 37: 51-53, 1992

13. Pfeiffer, Friede RL: Unilateral hydrocephalus from early developmental occlusion of one foramen of Monro. Acta Neuropathol 64: 75-77, 1984

14. Tien R, Harsh GR 4th, Dillon WP, Wilson CB: Unilateral hydrocephalus caused by an intraventricular venous malformation obstructing the foramen of Monro. Neurosurgery 26: 664666,1990

15. Venkataramana NK, Kolluri VR, Swamy KS, Arya BY, Das BS, Reddy GN: Progressive unilateral hydrocephalus in adults. Neurosurgery 24: 282-284, 1989

16. Wilberger JE Jr, Vertosick FT Jr, Vries JK: Unilateral hydrocephalus secondary to congenital atresia of the foramen of Monro. Case report. J Neurosurg 59: 899-901, 1983 